\title{
Best Practices in e-Assessment
}

\section{Nicole A. Buzzetto-More and Ayodele Julius Alade University of Maryland Eastern Shore, Princess Anne, MD, USA}

\section{Nabuzzetto-more@umes.edu ajadlade@umes.edu \\ Executive Summary}

According to Martell and Calderon (2005), assessment is an ongoing process that involves planning, discussion, consensus building, reflection, measuring, analyzing, and improving based on the data and artifacts gathered about a learning objective. Assessment encompasses a range of activities including testing, performances, project ratings, and observations (Orlich, Harder, Callahan \& Gibson, 2004).

Impacting education from early childhood through graduate studies, the assessment movement is based on standards and outcomes, measuring results, and holding educational institutions accountable for student learning. Oversight bodies and accrediting agencies are beginning to require the establishment of learner-centered outcomes that reflect the well-rounded knowledge, competencies, and abilities preferred in today's students; the alignment of curriculum to reflect the desired progression and cognitive development of learners; the collection of data that demonstrates the satisfaction of learning objectives; and the use of assessment information to inform decision making (Buzzetto-More, 2006).

The use of information technologies and e-learning strategies can provide an efficient and effective means of assessing teaching and learning effectiveness by supporting traditional, authentic, and alternative assessment protocols (Bennett, 2002). According to Vendlinski and Stevens (2002) technology offers new measures for assessing learning that will yield rich sources of data and expand the ways in which educators understand both learning mastery, and teaching effectiveness. The use of information technologies and e-learning to augment the assessment process may include: pre and post testing, diagnostic analysis, student tracking, rubric use, the support and delivery of authentic assessment through project based learning, artifact collection, and data aggregation and analysis.

The purpose of this paper is to provide insight into the origins, evolution, and key concepts of assessment as well as illustrate some of the ways in which technology and e-Learning serve as the most promising mechanisms for satisfying assessment goals and objectives.

This work is based on an exhaustive review of literature, the analysis of a number of critically acclaimed assessment programs, as well as the authors' own work in the development and use of e-Learning in the design, and implementation of an assessment program at a mid-sized institution

Material published as part of this journal, either on-line or in print, is copyrighted by the publisher of the Journal of Information Technology Education. Permission to make digital or paper copy of part or all of these works for personal or classroom use is granted without fee provided that the copies are not made or distributed for profit or commercial advantage AND that copies 1) bear this notice in full and 2) give the full citation on the first page. It is permissible to abstract these works so long as credit is given. To copy in all other cases or to republish or to post on a server or to redistribute to lists requires specific permission and payment of a fee. Contact Editor@JITE.org to request redistribution permission. of higher education located in the rural Eastern Shore of Maryland in the United States. The program being profiled includes computerized longitudinal testing, online diagnostic testing, competitive networked simulations, rubrics, student discussion transcripts, taped presentations, and electronic portfolios. 
Keywords: e-assessment, assessment, e-learning, e-portfolios, assessment data management

\section{History and Evolution of the Assessment Movement}

Assessment is not new to academia, with the roots of the current movement dating back over two decades (Martell \& Calderon, 2005). But two decades hardly take us back to the origins of educational assessment in the United States. According to Pearson, Vyas, Sensale, and Kim (2001), assessment of student learning has been gaining and losing popularity for well over 150 years.

In K-12 education, assessment first emerged in America in the 1840's, when an early pioneer of assessment, Horace Mann, used standardized written examinations to measure learning in Massachusetts (Pearson et al., 2001). After losing momentum, the scientific movement of the 1920's propelled the use of large-scale testing as a means of assessing learning (Audette, 2005). The 1960's saw further support of standardized testing when the National Assessment of Educational Progress was formed, which produced the Nation's Report Card (Linn, 2002). But perhaps no initiative has had as broad and pervasive an impact as the No Child Left Behind Act of 2001 (NCLB), which formally ushered us into an age of accountability. The NCLB act is a sweeping piece of legislation that requires regularly administered standardized testing to document student performance. The NCLB act is based on standards and outcomes, measuring results, and holding schools accountable for student learning (Audette, 2005). In 2006 Congress is required to reauthorize the Higher Education Act and it is predicted that NCLB will lead to changes in Higher Education Assessment requirements (Ewell \& Steen, 2006).

In higher education, the first attempts to measure educational outcomes emerged around 1900 with the movement to develop a mechanism for accrediting institutions of higher education (Urciuoli, 2005). In 1910 Morris Cooke published a comparative analysis of seven higher education institutions including Columbia, Harvard, Princeton, MIT, Toronto, Haverford, and Wiscon$\sin$. The result of the report was the establishment of the student credit hour as the unit by which to calculate cost and efficiency (Urciuoli, 2005). By 1913 accreditation in higher education had spread nation wide with the formation of a number of accrediting bodies (Urciuoli, 2005). The United States is unusual in that it relies on private associations rather than government agencies to provide accreditation of academic institutions and programs.

A number of reports released in the mid 1980's charged higher education to focus on student learning (Old Dominion University, 2006). During that time, the first formal assessment group was established, the American Association for Higher Education (AAHE) Assessment Forum, formed in 1987. In 1992, accrediting agencies were required to consider learning outcomes as a condition for accreditation following a 1992 Department of Education mandate (Ewell \& Steen, 2006).

Assessment experts point to pioneers of the assessment movement, Alverno College and Northeast Missouri State University, which have both been committed for over three decades to outcomes-based instruction. Kruger and Heisser (1987) who evaluated the Northeast Missouri State University assessment program found that the variety of assessments and questionnaires employed as well as the use of a longitudinal database that provides multivariate analysis makes this institution an exemplar in the effective us of quality assessment to support sound decision making.

The oldest recognized undergraduate assessment program in the United States can be found at the University of Wisconsin which has reported on some form of student outcomes assessment continuously since 1900 (Urciuoli, 2005).

The assessment movement is not limited to the United States. In the United Kingdom, the Higher Education Funding Council was established following the Further and Higher Education Act of 
1992, requiring the assessment of quality of education in funded institutions. In 2004, the Higher Education Act was passed with the goal of widening access to higher education as well as keeping UK institutions competitive in the global economy (Higher Education Funding Council for England, 2005). The formation of the Europe Union has created a need for the communication of educational quality. According to Urciuolo (2005) educational discourse in Europe and the UK are becoming dominated with the terms standards and accountability which were born and have been growing within the United States for many years.

\section{Understanding Assessment}

Haken (2006) explained that assessment is an integral piece to assuring that an educational institution achieves its learning goals, as well as a crucial means of providing the essential evidence necessary for seeking and maintaining accreditation. Hersh (2004) advocated the position that assessment of student learning should be considered an integral part of the teaching and learning processes as well as part of the feedback loop that serves to enhance institutional effectiveness.

Good assessment serves multiple objectives (Swearington, n.d.) and benefits a number of stakeholders (Love \& Cooper, 2004). According to Dietal, Herman, and Knuth (1991) assessment provides an accurate measure of student performance to enable teachers, administrators, and other key decision makers to make effective decisions. As a result, Kellough and Kellough (1999) identified seven purposes of assessment:

1. Improve student learning;

2. Identify students' strengths and weaknesses;

3. Review, assess, and improve the effectiveness of different teaching strategies;

4. Review, assess, and improve the effectiveness of curricular programs;

5. Improve teaching effectiveness;

6. Provide useful administrative data that will expedite decision making; and

7. To communicate with stakeholders.

Most individuals in the assessment community believe that the assessment process begins with the identification of learning goals and measurable objectives (Martell \& Calderon, 2005) as well as the use of specific traits that help define the objectives being measured (Walvoord \& Anderson, 1998). These traits are frequently correlated with the developmental concepts articulated in Bloom's Taxonomy of Educational Objectives which provides a recognized set of hierarchical behaviors that can be measured as part of an assessment plan (Harich, Fraser, \& Norby, 2005). There are six levels of Bloom's Taxonomy that relate to cognitive growth: knowledge, comprehension, application, analysis, synthesis, and evaluation. The three upper levels of Bloom's Taxonomy -- analysis, synthesis, and evaluation -- are linked to critical thinking. Figure 1 illustrates the taxonomy in its hierarchical structure.

Petkov and Petkova (2006) recommend course-embedded assessment as having the advantage of ease of implementation, low cost, timeliness, and student acceptance and note that the type of performance appraisal supported by rubrics is particularly effective when assessing problem solving, communication and team working skills. They explain that rubrics should not be considered checklists but rather criteria and rating scales for evaluation of a product or performance. According to Aurbach (n.d.), rubrics articulate the standards by which a product, performance, or outcome demonstration will be evaluated. They help to standardize assessment, provide useful data, and articulate goals and objectives to learners. Rubrics are also particularly useful in assessing complex and subjective skills (Dodge \& Pickette, 2001). 
Figure 1:

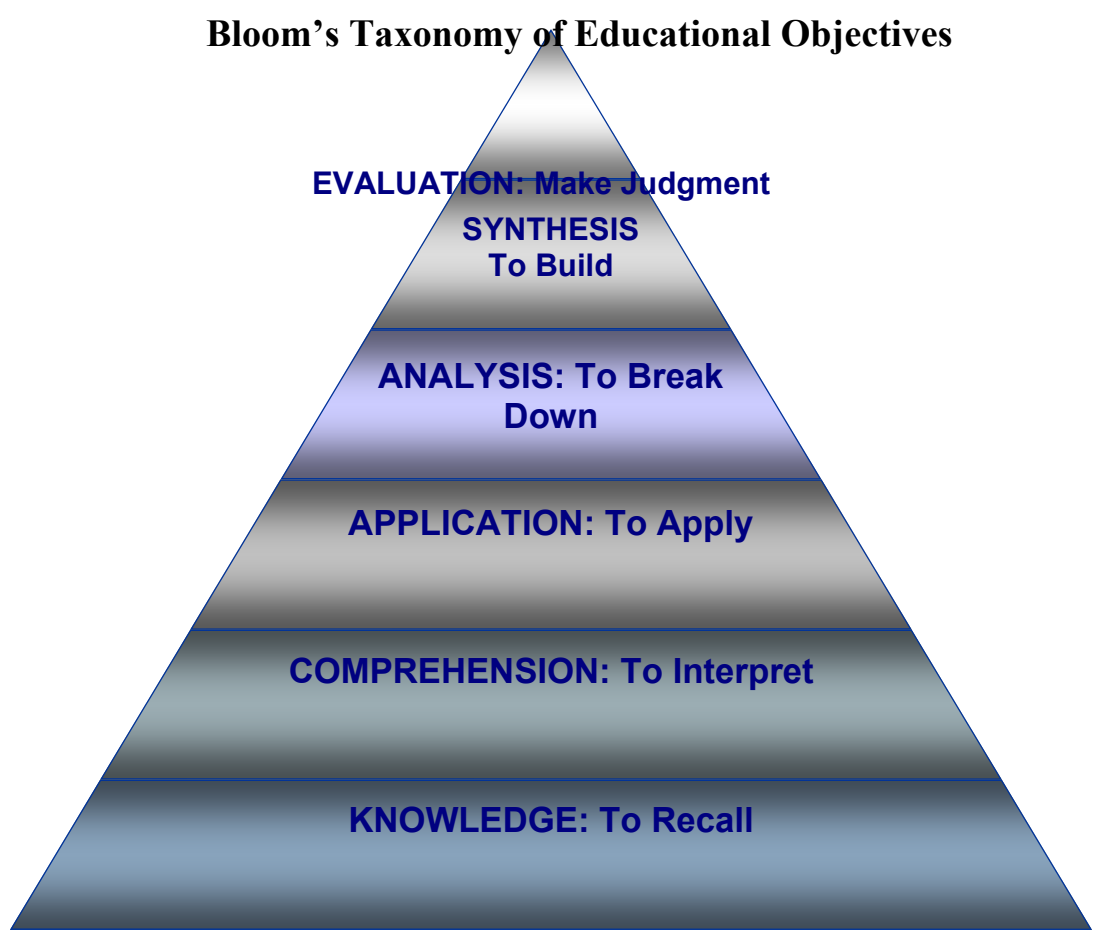

Petkov and Petkova (2006) who implemented rubrics in introductory IS courses found that the use of rubrics helped to make assessment more uniform, better communicate expectations and performance to students, measure student progress over time, and help to lay the foundation for a long-terms assessment program that combines projects and portfolios.

Measuring students' knowledge, strengths, and weaknesses prior to instruction is done through diagnostic testing (Swearington, n.d.). Diagnostic assessment allows educators to remedy deficiencies as well as make curricular adjustments.

Haken (2006) explained that it is important to measure knowledge; however, measuring knowledge is not enough. Hence, the current charge in education is to transform learning and assessment from the world of memorized facts to a broad, well-rounded model that reflects the learnercentered outcomes of an academic program (Wright, 2004). As a result, an academic program should work on building as well as assessing students' critical-thinking skills (Haken, 2006). According to Walcott (2005), who examined business education, examples of critical thinking can be found in the creation of marketing plans, the interpretation of financial statement ratios, the recommending of organizational restructuring, identifying and analyzing ethical issues, case studies, evaluating a company's strengths and weaknesses, and portfolio creation.

Portfolios can be used to assess learning-outcome achievement as well as to diagnose curriculum deficiencies that require improvement (Popper, 2005). Popper explained that portfolios should include a variety of samples of student work. According to the American Association of Higher Education (2001), portfolios have a broad application in a variety of contexts for the collection of meaningful evidence about learning outcomes. According to Chun (2002), a portfolio should require students to collect, assemble, and reflect on samples that represent the culmination of their learning. Cooper (1999) identified six considerations of the portfolio building process: identifica- 
tion of skill areas, design of measurable outcomes, identification of learning strategies, identification of performance indicators, collection of evidence, and assessment.

Wiggins (1990) suggests that work being assessed should be authentic or based on the real world. Pellegrino, Chudonsky, and Glaser (2001) suggest that formative assessments focus less on student responses and more on performance. As a result, many institutions are anchoring their assessment activities into meaningful scenarios so that students are being assessed on their abilities to apply learning into realistic situations.

An assessment center is not a physical place like the name implies, but rather is a suite of exercises that are designed to replicate real life and require participants to engage in a simulation. Participants are assessed based on their real time reactions and performance (Liam et. al, 2003). Assessment Centers were first introduced in the United Kingdom in the early 1940's. They were soon adopted within the United State growing in popularity in the 1950's in corporate American where they were used by such companies as AT\&T, Standard Oil, IBM, and General Electric (Liam Healy \& Associates, 2003). Assessment centers have been slowly growing in higher education over the past two decades. Most commonly they are found within schools of business. They are uncommon in K-12 education; however, High Tech High School in San Diego, California has found great success with their assessment center which places learners in environments that mimic the work place and are facilitated by parents, teachers, and workplace mentors (Page, 2006).

Value-added assessment demonstrates the progress of student learning throughout a program (Martell \& Calderon, 2005). It requires academics to ask "What do our students know, and how can we demonstrate that knowledge has been gained?" Value-added assessment commonly involves pre- and post-testing as well as student tracking. According to Carol Geary Schneider (2002), president of the American Association of Colleges and Universities, in order for valueadded assessment to be effective it must be longitudinal, embedded within credit-bearing courses, and have weight in determining student grades.

Regardless of the assessment measures being implemented, the literature suggests that good assessment programs have variety (Swearington, n.d.). Merrimack College, for example, uses diagnostic testing, student portfolios, alumni surveys, course evaluations, rubrics, and employer surveys as part of their assessment model (Popper, 2005).

Curricular alignment occurs when a program organizes their teaching and learning activities to reflect desired student outcomes (Martell \& Calderon, 2005). According to Baratz-Snowden (1993), curriculum alignment holds a school accountable for demonstrating when and where students have the opportunity to learn information and acquire skills. Engaging in curriculum alignment encourages programs to link outcomes to instruction as well as reflect upon the sequence in which competencies are built. Audette (2005) explained that curriculum alignment is particularly important to K-12 schools faced with high-stakes standardized tests. His study, conducted in the Massachusetts high school where he serves as principal, showed tangible improvement in standardized test scores as a result of curriculum alignment.

Successful assessment is an ongoing cycle that involves the identification of outcomes, the gathering and analyzing of data, discussion, suggesting improvements, implementing changes, and reflection that has been depicted in Figure 2.

The assessment process is represented as a continuous cyclical process or, rather, a loop. "Closing the loop" is a popular term in the assessment movement that has been defined by Martell and Calderon (2005) as ongoing process that uses assessment data to improve student outcomes. 
Figure 2: The Assessment Process based on Martell \& Calderon, 2005

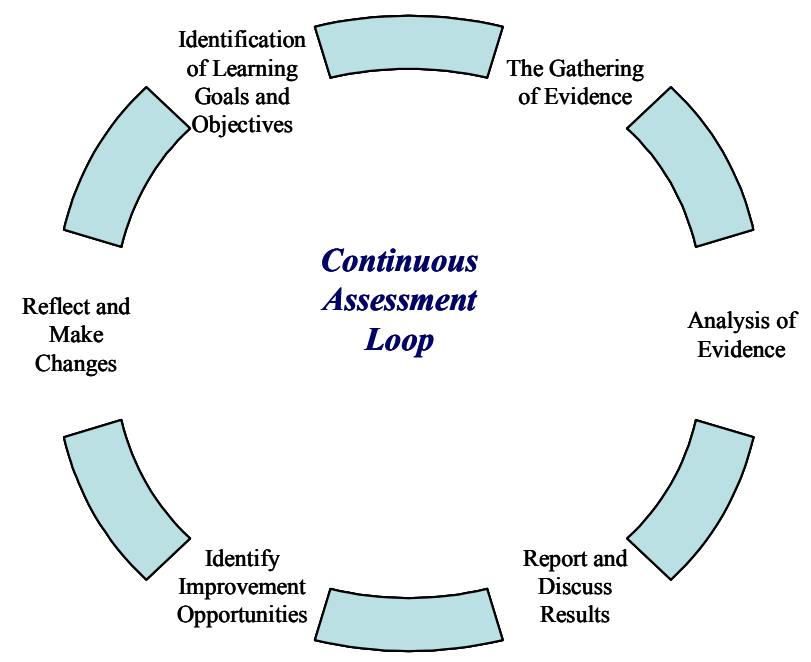

The assessment process is dependent on the collection of high-quality data that provides a basis to evaluate all of a program's learning objectives. As a result, effective data

Not all data is useful data, and the assessment process is dependent on the collection of high-quality data that provides a basis to evaluate all of a program's learning objectives (Martell \& Calderon, 2005). As a result, effective data management is crucial to the assessment loop (Dhir, 2005), where the data collected needs to be made available to faculty and administrators in a timely manner so that fact-based decisions can be made. Dhir (2005) explains that when data is readily accessible, a dialogue can occur that focuses on the critical issues at stake.

\section{e-Learning and e-Assessment}

Learning that is facilitated by electronic technologies; otherwise known as e-Learning, encompasses a number of activities that may or may not include the use of networked or web-based digital technologies. E-Learning may be web-assisted, or classroom learning that is facilitated by the use of a course website and the World Wide Web; or the mixture of classroom and online instruction known as the hybrid or adjunct model; or a fully online experience where all instruction and assessment occurs electronically (Buzzetto-More \& Guy, 2006).

According to Bennett (2002), technology is central to learning and, as a result, is going to prove to be central to the assessment process. Bennett explains that technology will not only facilitate testing but also support authentic assessment. He refers to e-learning as part of the equipment of $21^{\text {st }}$ Century scholarship and cites the success of online universities and virtual high schools in the United States.

According to the March 2006 issue of T.H.E. Journal of Technological Horizons in Education, widening achievement gaps and government mandates have required schools to use data to inform decision making, an activity that has coincided with improved information technologies, high-speed internet, and easy to use computer applications (Petrides, 2006).

Numerous studies have linked e-learning to critical thinking; for example, a study of 300 recent MBA graduates conducted at the University of Wisconsin-Whitewater found that online learning encourages high level reflective thinking (Drago, 2004).

Whereas e-learning has been part of our educational vernacular for some time, e-assessment is a fairly new term. Ridgway, McCusker, and Pead (2004) define e-assessment as the use of electronic technologies to drive student learning assessment. They say that e-assessment should encourage the rethinking of curriculum, e-learning, and technology and explain that e-assessment is flexible and supports the assessment of higher order thinking, social skills, and group work through such means as digital portfolios 
Vendlinski and Stevens (2002) illustrate that technology provides new means to assess learning that will yield rich sources of data. E-assessment may include pre and post testing, diagnostic analysis, student tracking, rubric use/analysis, the support and delivery of authentic assessment through project based learning (e.g. WebQuests, simulations, eportfolios), artifact collection, and data aggregation and analysis. (Buzzetto-More, 2006).

Computerized delivery and analysis of diagnostic or traditional testing is increasing in popularity. According to Hamilton and Shoen (2005), web-based testing has significant advantages in the areas of cost, ease of use, reliability, replicability, scoring, aggregating results, and data management. They explain that digital assessment measures can score themselves with great reliability and no subjectivity while making data available with immediacy. Texas Christian, for example, requires students entering its business program to complete a computerized diagnostic test in order to collect meaningful data about incoming students (Gay, 2005).

Rubrics can be translated to a digital format where they may be made available through an intranet or over the internet. Used for scoring, these scores provide meaningful assessment information. When connected to a database, they provide educators with data that can be aggregated (Buzzetto-More, 2006). There are a number of websites that assist teachers in the development of rubrics. Two useful rubric builders can be found at http://rubistar.4teachers.org and http://landmark-project.com

As mentioned earlier, experts suggest that work being assessed should be authentic or based on the real world (Wiggins, 1990). Frequently known as project based learning, it is a form of instruction where students are immersed in challenging learning situations that are anchored in real world simulations (Page, 2006). According to Page, project based learning can support critical thinking, multilayered decision making, goal setting, problem solving, and collaboration. As a result, many institutions are anchoring their assessment activities into meaningful scenarios so that students are being assessed on their abilities to apply learning into realistic situations.

The World Wide Web contains numerous project based learning activities as well as a variety of mechanisms for their development, hosting, and or support (Page, 2006). GlobalSchool.Net is an excellent resource for gaining information on project based learning. Another great resource is the WebQuest.

A WebQuest is an inquiry-oriented learning activity where the majority of information that learners interact with comes from web resources (Dodge, 1995). Bernard Dodge of San Diego State University, the developer of the WebQuest, explained that WebQuests give students clarity and a purpose to online queries by encouraging students to compare, classify, analyze, evaluate, and synthesize. WebQuests have been developed for all levels of education from elementary through adult education. There are variations among WebQuests; however, all should contain the following elements:

- An introduction that provides a narrative and background information.

- A task that is meaningful, realistic, and interesting.

- A set of resources needed to complete the task.

- A clear description of the process or steps for accomplishing the task.

- Some guiding questions or directions on how to organize the information acquired. Templates, timelines, concept maps, or cause-and-effect diagrams as described may also be included.

- An evaluation section that explains how performance will be assessed.

- A conclusion that brings closure and reminds learners about what they have gained. 
Computer simulations are a form of project based learning that require learners to discover and apply learned skills interactive changing environments that mimic real-world situations (Berge 2002). Vendlinski and Stevens (2002) recommend the IMMEX multi-media exercise software, a web based simulation authoring, presentation, and assessment tool. Granland, Bergland, and Erikson (2000) reviewed three different web-based simulations at three different universities and found that the simulations encouraged critical thinking and discovery learning; however, they also noted the lack of quality assessment measures available to evaluate student simulations. As a result, educators are increasingly finding the value of using rubrics to fully evaluate simulation participation because the score or end result is not always indicative of the students thought processing and participation (Buzzetto-More, 2006).

Studies by Garrison, Anderson, and Archer (2004) found that online discourse fosters critical thinking and reflection, and $\mathrm{Wu}$ and Hiltz (2004) explained that asynchronous communications improved students' perception of learning. A study conducted in the United Arab Emirates indicated that students who are reluctant to participate in classroom discussions are more vocal in electronic discussions and that discussions increase understanding of course content (Bhatti, Tubaisahat, \& El-Quawasmeh, 2005). Successful online discussions can allow students to demonstrate not just content mastery but the ability to incorporate content into higher level thinking; as a result, transcripts from electronic discussions have shown themselves to be valuable assessment artifacts (Buzzetto-More, 2006).

According to the American Association of Higher Education (2001), portfolios have a broad application in a variety of contexts for the collection of meaningful evidence about learning outcomes. Portfolios are an effective form of alternative assessment that encourages students and educators to examine skills that may not be otherwise accessed using traditional means such as higher order thinking, communications, and collaborative abilities (Buzzetto-More, 2006; Wright, 2004). According to the ePortConsortium (2003) the benefits of electronic portfolios in education are that they help students develop organizational skills; recognize skills, abilities, and shortcomings; showcase talents; assess academic progress; demonstrate how skills have developed over time; make career decisions; demonstrate that one has met program or certification requirements; and promote themselves professionally.

A portfolio should require students to collect, assemble, and reflect on samples that represent the culmination of their learning (Chun, 2002) providing students with a diversity of opportunities to skills and abilities (Martell \& Calderon, 2005). New High Tech High School in Napa, California involves students in long-term technology dependent portfolio projects (Page, 2006) and the business program at Merrimack College, has students engaged in an ongoing portfolio building process throughout their time in the program where students revisiting their portfolio will be able to observe their own growth (Popper, 2005).

Online portfolios have a number of advantages over those that are paper based as they support: a greater variety of artifacts and allow for greater learner expression; are dynamic and multimedia driven; accessible by a large audience; contain meta-documentation; easy to store; and may serve to promote a student academically or professionally (Buzzetto-More, 2006).

The collection of artifacts contained within a student learning portfolio can include text based items, graphic or multimedia driven elements, websites, and/or other items captured in an electronic format (Lorenzo \& Ittelson, 2005a). According to Lorenzo and Ittelson (2005b) the skills required in the creation of electronic portfolios helps students learn, understand, and implement the information literacy process.

Information literacy is the ability to collect, evaluate, assemble, reflect upon, and use information in order to learn and inform problem-solving and decision making (Bruce, 2003). It is a skill crucial to lifelong learning that is dependent on the ability to engage in critical and reflective think- 
ing (Bruce, 2003). Electronic portfolios are quickly becoming the primary means in academia for students to demonstrate and reflect on learning in a way that helps students build and apply information literacy skills (Lorenzo \& Ittelson, 2005a).

Many teacher education programs have successfully incorporated e-portfolios into their curricula as a means to satisfy current National Council for Accreditation of Teacher Education (NCATE) standards. These systems frequently incorporate the use of scoring rubrics that collect statistical data for later aggregation (Barett, 2004). Popular systems include: TaskStream, LiveTech, TK20, Foliotek, FolioLive, ePortfolio, TrueOutcomes, and SpringBoard. The two biggest companies offering course management systems WebCT and Blackboard have merged and have begun piloting their new electronic portfolio system which will be available as an add on product in the future.

Other technologies that are gaining in popularity in e-assessment include pen top computing (which allows teachers to review, comment, add to, and access handwritten student notes and work), integrated student response keypads (which allow for real time whole class questioning and data collection and analysis), pod casting (recording and distributing small audio and video files to students via their handheld devices), and digital video/audio lecture capturing synched with tablet pc presentations and activities (providing an archived record of teaching effectiveness for assessment demonstration). All of the aforementioned technologies not only augment the teaching and learning process but also provide data and/or artifacts that can help to satisfy assessment objectives (Buzzetto-More, 2006).

In order to expedite the data collection and review process, many schools are choosing to automate their data collection, storage, and analysis, which has been identified as a best practice by Hamilton and Shoen (2005). Assessment data management systems are frequently web-based and made available by a university's intranet, with a system of priority based accessibility in order to ensure data security (Dhir, 2005). They may include data collected from rubrics, portfolios, student placement tests, diagnostic tests, grades, advisement information and participation in university activities, use of remediation services, technology use, attendance, and other useful information (Dhir, 2005). According to Love and Cooper (2003), assessment systems must take into account issues of interface, accessibility, security, usability, the information to be collected, hardware and software technology, and information storage and processing.

Berry College's business department employs a detailed web-based assessment management system that in addition to containing crucial assessment data also includes process maps of the various procedures that occur throughout the institution and that occur in individual schools, departments, and or offices (Dhir, 2005). The business program at Merrimack College considers their data management system crucial to their assessment process, allowing them to produce assessment reports, school and department assessment portfolios, and make information available to a variety of stakeholders with varying degrees of accessibility online (Popper, 2005).

Western Washington University is currently developing a school-wide assessment data system that will allow administrators to access pertinent assessment data through their secure intranet $d$ and Wake Forest University which puts a laptop in the hands of all of their students also puts their course evaluations online enabling immediate analysis of evaluations as well as the ability to aggregate the data collected (National Center for Postsecondary Education [NCPE], 2001).

Assessment data management systems (often referred to as dashboard indicators) are available for purchase and are frequently web-based and made available by a school or districts intranet, with a system of priority based accessibility in order to ensure data security (Dhir, 2005). Northwest Missouri University uses a system of dashboards to facilitate their assessment program. Their assessment information is distributed through a networked system of linked and queriable spreadsheets that are referred to as dashboards and profiles (NCPE, 2001). 


\section{An e-Learning Facilitated Assessment Model in a Mid-Sized Business Department}

After conducting an extensive review of the prevailing literature, examining a variety of assessment models, and investigating a number of projects; a business department at a four year institution of higher education in Maryland, driven by their application for accreditation by the American Association of Colleges and School of Business International (AACSB), has developed an assessment plan that they consider to be both ambitious and practical. They believe that the plan when fully implemented will result in a tangible improvement in the total teaching and learning experience. The process, which has been long in its development, was initiated with the development and articulation of a mission, goals, and measurable learner outcomes (Table 1)

Table 1: Department of Business Management \& Accounting Core Curriculum Mission, Goals, \& Outcomes

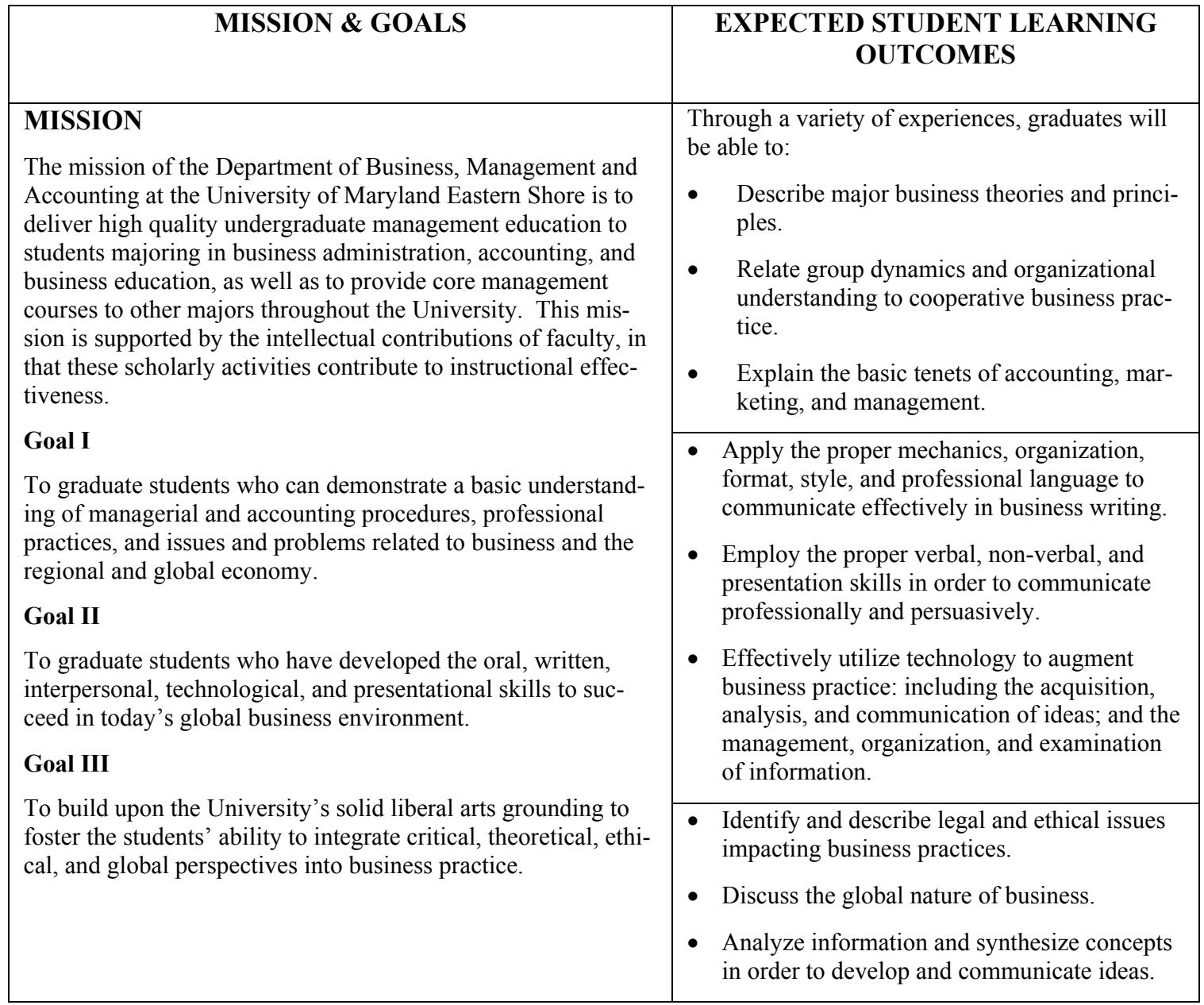

The University of Maryland Eastern Shore is a public institution and the student body is approximately 3,700 , with $10 \%$ of the enrollment representing graduate students. Located in a rural region, it is the most affordable four-year institution of higher education in the state. The Department of Business, Management, and Accounting is one of the largest departments on campus with approximately 420 majors, offering programs that include Business Management, Marketing, Accounting, and Business Education. 


\section{Measuring the Knowledge and Comprehension of Students}

Sometimes in the assessment game, educators are able to build on a program already in existence. Such was the case with the measurement of student knowledge and comprehension. For a number of years, all students enrolled in the Department of Business, Management and Accounting have been required to take three professional development seminars at the freshman, sophomore, and junior levels. Historically, a take-home multiple-choice test has been administered to measure student knowledge and comprehension of key business concepts. The same test has always been administered in each seminar in order to track the knowledge gained during the students' progression through the program.

As part of the current assessment initiative, this test is being transferred to an online format to be delivered and graded via the WebCt course management system. Rather than remaining openbook, the exam will be delivered in a proctored computer lab, where the scores will be automatically calculated and stored for comparative analysis. By tracking student knowledge and comprehension of core content as it is built during the students' progression through the program, the department is conducting value-added assessment. The online version of the test will be available in the fall of 2006 .

\section{Student Communications Skills}

The written and oral presentation abilities of business students are skill-based competencies that are crucial to the future career successes of today's business graduates. Professional presentations are required of students across the programs curriculum, increasingly in complexity gradually. Business writing is enhanced in a dedicated course, business communications, that is required of all students enrolled within the department who have previously completed the written and oral communications requirements of the university.

Business communications runs as a paperless hybrid learning experience using the WebCT course management system. Hybrid courses blend face-to-face interaction with online learning and involve the online delivery of lectures and other curricular materials (Buzzetto-More \& Guy, 2006). In order for a course to be considered hybrid, some seat time must be forfeited to accommodate the additional weight put on the online work. Recently, the use of Tegrity has been added to the course, enabling the instructor to capture key lectures with live audio synched with screencaptured video from the instructor's tablet computer. The technology used and the content of this course have enabled it to become part of two separate assessment protocols examining written and presentational communications, respectively.

\section{Writing}

Online diagnostic testing of student writing is administered at two junctures during business communications. A diagnostic test focuses on: sentence structure, subject-verb agreement, pronouns, adjectives and adverbs, verbs, as well as numerous aspects of grammar. The test is administered twice and the diagnostic results of the first test are evaluated and communicated to students within the first two weeks of the semester. Students are provided with a number of webbased resources to improve their deficiencies, and, if necessary, remediation is recommended. The second diagnostic, which occurs later in the semester, is used to assess student progress toward enhancing their strengths and rectifying their weaknesses. The test is made available through the course website and the online diagnostic system being used makes a variety of reports available for analysis.

A business-writing portfolio is also assigned and collected digitally. The written portfolio is accessed using a common rubric. Sample student portfolios and corresponding rubrics are archived as assessment artifacts. 
A writing competency exam is administered following the completion of the course and passage of the exam is a requisite to graduation. To assist in the assessment process, the department's writing rubric is being utilized. Samples of the exam is collected, without identifying information, and annually reviewed using the standards set forth in the rubric (see Table 2) by an assurance of learning committee. The committee is charged with identifying areas that require improvement and determining a course of action. Additionally, although the exam is currently paper based, the pass-fail rates of students are calculated and stored. Currently, a plan is in place to transfer the exam to a digital format where it can be administered in a lab.

Table 2: Writing Assessment Rubric

\begin{tabular}{|c|c|c|c|c|}
\hline & $\begin{array}{c}\text { Unacceptable or } \\
\text { Lacking }\end{array}$ & Developing & Satisfactory & Exemplary \\
\hline Format & $\begin{array}{l}\text { Proper form not ap- } \\
\text { plied. }\end{array}$ & $\begin{array}{l}\text { Evidence at attempt at format- } \\
\text { ting provided. }\end{array}$ & Acceptable formatting. & $\begin{array}{l}\text { Perfect formatting. Proper } \\
\text { headings and footings. All } \\
\text { stylistic elements included. }\end{array}$ \\
\hline $\begin{array}{l}\text { Introduction/ } \\
\text { Thesis }\end{array}$ & $\begin{array}{l}\text { No discernible intro- } \\
\text { duction or thesis. }\end{array}$ & $\begin{array}{l}\text { Attempt demonstrated; how- } \\
\text { ever, it is incomplete (e.g. not } \\
\text { summative, does not prepare } \\
\text { readers, missing thesis). }\end{array}$ & $\begin{array}{l}\text { Contains all the necessary } \\
\text { elements; however, improve- } \\
\text { ment is needed in order to } \\
\text { maximize its effectiveness. }\end{array}$ & $\begin{array}{l}\text { Gains attention, is summa- } \\
\text { tive, contains all crucial } \\
\text { information, flows seam- } \\
\text { lessly, and is absent of } \\
\text { errors. }\end{array}$ \\
\hline Organization & $\begin{array}{l}\text { Sequence of ideas is } \\
\text { not logical. }\end{array}$ & Somewhat unorganized. & $\begin{array}{l}\text { Adequate, some improvement } \\
\text { is needed. }\end{array}$ & $\begin{array}{l}\text { Well organized and flowed } \\
\text { seamlessly. }\end{array}$ \\
\hline Focus & $\begin{array}{l}\text { Focus was unclear or } \\
\text { disjointed. }\end{array}$ & Somewhat unfocused at times. & $\begin{array}{l}\text { Adequate, some improvement } \\
\text { is needed. }\end{array}$ & $\begin{array}{l}\text { The work was focused } \\
\text { throughout. }\end{array}$ \\
\hline Clarity of Purpose & No clarity of purpose. & Work was unclear at times. & $\begin{array}{l}\text { Adequate, some improvement } \\
\text { is needed. }\end{array}$ & $\begin{array}{l}\text { Clear and concise through- } \\
\text { out. }\end{array}$ \\
\hline $\begin{array}{l}\text { Knowledge of } \\
\text { Subject }\end{array}$ & $\begin{array}{l}\text { The author appeared } \\
\text { largely uninformed } \\
\text { about the topic. }\end{array}$ & $\begin{array}{l}\text { The author indicated some } \\
\text { attempt at understanding the } \\
\text { topic. }\end{array}$ & $\begin{array}{l}\text { Adequate knowledge illus- } \\
\text { trated; however, improvement } \\
\text { is needed. }\end{array}$ & $\begin{array}{l}\text { The author was clearly well } \\
\text { versed on the subject. }\end{array}$ \\
\hline Mechanics & $\begin{array}{l}\text { Numerous errors were } \\
\text { evident in spelling, } \\
\text { grammar, and/or } \\
\text { usage. }\end{array}$ & $\begin{array}{l}\text { Some spelling, grammar, } \\
\text { and/or usage errors were } \\
\text { present. }\end{array}$ & The work had few errors. & $\begin{array}{l}\text { The work was error free } \\
\text { requiring no editing. }\end{array}$ \\
\hline $\begin{array}{l}\text { Supporting } \\
\text { Information }\end{array}$ & $\begin{array}{l}\text { No supporting infor- } \\
\text { mation was offered. }\end{array}$ & $\begin{array}{l}\text { Some supporting information } \\
\text { was offered but insufficient. }\end{array}$ & $\begin{array}{l}\text { Adequate; however, some } \\
\text { improvement and/ or additions } \\
\text { needed. }\end{array}$ & $\begin{array}{l}\text { Exemplary with the addi- } \\
\text { tion of evidence, facts, data, } \\
\text { and/or quotations. }\end{array}$ \\
\hline Wording & $\begin{array}{l}\text { Language, tone, and/or } \\
\text { vocabulary used were } \\
\text { not appropriate. }\end{array}$ & $\begin{array}{l}\text { Some problems with the } \\
\text { language, tone, or vocabulary. }\end{array}$ & $\begin{array}{l}\text { Adequate language, tone, and } \\
\text { vocabulary. Improvement } \\
\text { needed. }\end{array}$ & $\begin{array}{l}\text { The language, tone, and } \\
\text { vocabulary were profes- } \\
\text { sional and appropriate. }\end{array}$ \\
\hline $\begin{array}{l}\text { Conclusion/ } \\
\text { Follow Up }\end{array}$ & $\begin{array}{l}\text { No conclusion, sum- } \\
\text { mary, and/or follow up } \\
\text { information provided. }\end{array}$ & There but weak & $\begin{array}{l}\text { Adequate, improvement is } \\
\text { needed. }\end{array}$ & $\begin{array}{l}\text { Clear, summative, and } \\
\text { concluding. }\end{array}$ \\
\hline
\end{tabular}

\section{Oral Presentations}

Student oral presentations are being assessed using a standard rubric (see Table 3 ) in three courses that represent three stages of a student's progression through the department. The courses are introduction to marketing, offered at the sophomore level; business communications, offered at the junior level; and the capstone course, offered to graduating seniors. For maximum effectiveness, multiple assessors are involved.

Student presentations are being recorded on video at random. Additionally, in an attempt to further communicate assessment and collect data, the Tegrity system is being used in random sections of business communications to record student presentations using a webcam synched with instructor assessment conducted through a rubric on the instructor's tablet computer. Students are able to visit the course website and review the presentations and instructor evaluation in a split 
screen format. This also enables student presentations to be maintained as part of the department's data/artifact collection.

Table 3: Professional Presentation Assessment Rubric

\begin{tabular}{|c|c|c|c|c|c|}
\hline CRITERIA & $\begin{array}{l}\text { Weak/ Unsatis- } \\
\text { factory }\end{array}$ & $\begin{array}{l}\text { Limited Under- } \\
\text { standing } \\
\text { Demonstrated }\end{array}$ & Satisfactory & $\begin{array}{c}\text { Good/Demonstrated } \\
\text { Understanding of } \\
\text { Skill }\end{array}$ & $\begin{array}{l}\text { Exceptional } \\
\text { Error Free }\end{array}$ \\
\hline INTRODUCTION & $\begin{array}{l}\text { Missing or } \\
\text { unclear. }\end{array}$ & $\begin{array}{l}\text { Doesn't prepare } \\
\text { audience. }\end{array}$ & $\begin{array}{l}\text { Attempt to prepare } \\
\text { audience/ include } \\
\text { thesis. }\end{array}$ & $\begin{array}{l}\text { Prepares audience, } \\
\text { contains thesis, needs } \\
\text { works. }\end{array}$ & $\begin{array}{l}\text { Well worded, pre- } \\
\text { pares the audience, } \\
\text { and summarizes. }\end{array}$ \\
\hline ORGANIZATION & $\begin{array}{l}\text { Lacked a logical } \\
\text { sequence or } \\
\text { flow. }\end{array}$ & $\begin{array}{l}\text { Some attempt made } \\
\text { but at times unorgan- } \\
\text { ized \& difficult to } \\
\text { follow. }\end{array}$ & $\begin{array}{l}\text { Adequate organiza- } \\
\text { tion that requires } \\
\text { improvement. }\end{array}$ & $\begin{array}{l}\text { Focused, organized } \\
\text { clearly, contained } \\
\text { transitions, and mostly } \\
\text { flowed well. }\end{array}$ & $\begin{array}{l}\text { Clearly ordered, } \\
\text { focused, flowed } \\
\text { smoothly, and utilized } \\
\text { transitions. }\end{array}$ \\
\hline $\begin{array}{l}\text { DELIVERY Verbal } \\
\text { (volume, tone, rate, vocal } \\
\text { variability, strategic } \\
\text { pauses, and pronuncia- } \\
\text { tion) }\end{array}$ & $\begin{array}{l}\text { Poor verbal } \\
\text { delivery. }\end{array}$ & $\begin{array}{l}\text { Some areas of verbal } \\
\text { delivery require major } \\
\text { improvement. }\end{array}$ & $\begin{array}{l}\text { Satisfactory but } \\
\text { improvement is } \\
\text { needed. }\end{array}$ & $\begin{array}{l}\text { Verbal delivery needs } \\
\text { only minor improve- } \\
\text { ments. }\end{array}$ & $\begin{array}{l}\text { Exemplary verbal } \\
\text { delivery that is well } \\
\text { polished. }\end{array}$ \\
\hline $\begin{array}{l}\text { DELIVERY Nonverbal } \\
\text { (posture, stance, eye } \\
\text { contact, gestures, move- } \\
\text { ment, facial expression, } \\
\text { and professional attire) }\end{array}$ & $\begin{array}{l}\text { Nonverbal } \\
\text { delivery is } \\
\text { significantly } \\
\text { flawed and } \\
\text { distracting. }\end{array}$ & $\begin{array}{l}\text { Some attempt at } \\
\text { preparation is evident. } \\
\text { Significant improve- } \\
\text { ment is needed. }\end{array}$ & $\begin{array}{l}\text { The presenter } \\
\text { shows evidence of } \\
\text { preparation. Im- } \\
\text { provement is } \\
\text { needed. }\end{array}$ & $\begin{array}{l}\text { Presentation is well } \\
\text { delivered and only } \\
\text { minor improvements } \\
\text { are needed in order to } \\
\text { polish delivery. }\end{array}$ & $\begin{array}{l}\text { The presentation is } \\
\text { professional and } \\
\text { polished in nature. } \\
\text { The delivery helps to } \\
\text { draw in the audience. }\end{array}$ \\
\hline $\begin{array}{l}\text { CONTENT (knowledge } \\
\text { of subject, supporting } \\
\text { material, grammar, } \\
\text { sentence structure, de- } \\
\text { velopment of ideas, and } \\
\text { professionalism }\end{array}$ & $\begin{array}{l}\text { Content is weak. } \\
\text { Ideas are poorly } \\
\text { developed. A } \\
\text { lack of prepar- } \\
\text { edness. }\end{array}$ & $\begin{array}{l}\text { Some attempt at } \\
\text { content development } \\
\text { is evident but needs } \\
\text { major improvement. }\end{array}$ & $\begin{array}{l}\text { The content is } \\
\text { adequate but more } \\
\text { preparation is } \\
\text { needed. }\end{array}$ & $\begin{array}{l}\text { The presenter was } \\
\text { well prepared with } \\
\text { strong content and } \\
\text { only minor errors. }\end{array}$ & $\begin{array}{l}\text { Exemplary content } \\
\text { that indicated an } \\
\text { outstanding effort on } \\
\text { the part of the pre- } \\
\text { senter. }\end{array}$ \\
\hline $\begin{array}{l}\text { VISUAL AIDS (if } \\
\text { applicable) }\end{array}$ & $\begin{array}{l}\text { Visual aides not } \\
\text { used. }\end{array}$ & $\begin{array}{l}\text { Visual aides used but } \\
\text { they were ill prepared. }\end{array}$ & $\begin{array}{l}\text { Adequate; how- } \\
\text { ever, some prob- } \\
\text { lems evident. }\end{array}$ & $\begin{array}{l}\text { Good usage with } \\
\text { minor improvements } \\
\text { needed. }\end{array}$ & $\begin{array}{l}\text { Supportive, illustrated } \\
\text { main points, and } \\
\text { created interest. }\end{array}$ \\
\hline CONCLUSION & $\begin{array}{l}\text { Either missing, } \\
\text { difficult to } \\
\text { discern, or } \\
\text { abrupt. }\end{array}$ & $\begin{array}{l}\text { Attempt evident but } \\
\text { weak. }\end{array}$ & $\begin{array}{l}\text { Adequate but needs } \\
\text { work. }\end{array}$ & $\begin{array}{l}\text { Good conclusion that } \\
\text { needs only minor } \\
\text { modifications. }\end{array}$ & $\begin{array}{l}\text { Outstanding- logical, } \\
\text { summative, clear, and } \\
\text { signals end. }\end{array}$ \\
\hline
\end{tabular}

\section{Critical Thinking}

\section{Case Studies}

The ability for students to analyze situations, evaluate and make judgments, and formulate solutions are critical-thinking skills, all of which case analysis requires. As a result, the department has begun testing the use of a common rubric (Table 4) to assess case studies completed by students in two sections of business ethics. In one section of the course, students are submitting their cases in a digital drop box in WebCT, where they are archived for future evaluation. Plans are in place to adopt the rubric in other courses such as marketing where case analysis is also a commonplace. 
Table 4: Case Analysis Rubric

\begin{tabular}{|c|c|c|c|c|}
\hline & Weak & Limited/ Adequate & Good & Outstanding \\
\hline Format & $\begin{array}{l}\text { Incorrect format } \\
\text { employed. }\end{array}$ & $\begin{array}{l}\text { Attempt limited improve- } \\
\text { ment is needed. }\end{array}$ & $\begin{array}{l}\text { Well formatted with minor } \\
\text { improvement needed. }\end{array}$ & Outstanding format. \\
\hline Organization & $\begin{array}{l}\text { Illogical or dis- } \\
\text { jointed organization. }\end{array}$ & $\begin{array}{l}\text { Attempt at organization } \\
\text { made but improvement is } \\
\text { needed. }\end{array}$ & $\begin{array}{l}\text { Satisfactory with only } \\
\text { minor improvement } \\
\text { needed. }\end{array}$ & $\begin{array}{l}\text { Outstanding- logical, } \\
\text { focused, and clear. }\end{array}$ \\
\hline Content & $\begin{array}{l}\text { Content was weak } \\
\text { main issues not } \\
\text { identified. }\end{array}$ & $\begin{array}{l}\text { Attempt to identify impor- } \\
\text { tant issues. Needs im- } \\
\text { provement. }\end{array}$ & $\begin{array}{l}\text { Satisfactory with only } \\
\text { minor additions or im- } \\
\text { provement needed. }\end{array}$ & $\begin{array}{l}\text { Excellent content that } \\
\text { presented all important } \\
\text { issues \& supporting mate- } \\
\text { rials. }\end{array}$ \\
\hline Mechanics & $\begin{array}{l}\text { Many errors in spell- } \\
\text { ing, grammar, struc- } \\
\text { ture, or syntax. }\end{array}$ & $\begin{array}{l}\text { Some unnecessary errors } \\
\text { evident. }\end{array}$ & Good with minor errors. & Virtually error free. \\
\hline Analysis & Weak analysis. & $\begin{array}{l}\text { Cursory analysis provided } \\
\text { that lacked depth. }\end{array}$ & $\begin{array}{l}\text { Satisfactory analysis that } \\
\text { needed only a little more } \\
\text { depth. }\end{array}$ & $\begin{array}{l}\text { Outstanding- all issues } \\
\text { identified, course concepts } \\
\text { applied, judgments made, } \\
\text { and ideas assembled. }\end{array}$ \\
\hline
\end{tabular}

\section{WebQuests}

Students enrolled in Business Communications are required to complete a business plan research and development group WebQuest and students enrolled in the Business Education program are required to create original WebQuests, as well as accompanying lesson plans. The teacher education major created WebQuests are evaluated using rubrics. The WebQuests completed by students in Business Communications as well as the WebQuests created by students majoring in Business Education are reviewed and archived.

\section{Simulations}

Simulations require critical thinking as well as the application of knowledge and skills in authentic anchored scenarios. Students in the department consistently rank nationally in competitive networked simulations, and the department considers these simulations to be an integral part of the student learning process. Simulations are done in several courses and are scaffolded through the curriculum where each simulation builds on knowledge and skills built in previous simulations. Computerized simulations can currently be found in several mandatory courses including marketing, entrepreneurship, and strategic management. The product Capstone $\mathbb{C}$, available through Management Simulations, Inc., is being utlilized. It involves students fulfill the roles of the managers of competing companies, making decisions in Research and Development, Production, Marketing, Finance, Human Resources and Total Quality Management (Mitchell, 2006).

Beginning in the spring of 2006, simulation scores and comparative data are being collected and reviewed. Additionally, because simulation results do not necessarily indicate the thought processing, knowledge application, analysis, synthesis, and evaluation being done by students, a rubric is being developed to assess students' engagement in simulations. This will help address a need that has been identified by both Lunce (2004) and Granland, Bergland, and Erikson (2000) as absent from the literature on the educational impact of online simulations. The rubric is currently under development and will be available for, and implemented in, the Fall 2006 semester.

\section{Student Portfolios}

Student portfolios are project-based learning activities that also serve as effective means of assessing learning-outcome achievement, by providing students flexible opportunities to demon- 
strating the acquisition of skills and abilities. An electronic portfolio has been adopted within the business education teacher education program using the TK20 portfolio assessment system. The electronic portfolios created by students include: lesson plans, WebQuests, student teaching videos, images, reflective journal entries, papers, transcripts, evaluations completed by cooperating teachers, observations made by their program advisor, student projects, rubrics, study aides, PowerPoint Presentations, websites, curriculum maps, goals and objectives, seating charts, behavior expectation sheets, assessment materials, progress reports, and a variety of other artifacts that demonstrate a students mastery of the principles established by the Interstate New Teacher Assessment and Support Consortium which have been adopted by the University. Portfolios are presented by the students and assessed using a simple rubric by a team of assessors. The portfolio is accessible to students for a period of seven years following their graduation from the program and has shown itself to be a useful resource for students applying for employment as it allows them to communicate a variety of skills and abilities in a dynamic format.

Impressed by the success of the capstone portfolio used in the business education teacher education program, an e-portfolio model is being introduced by the larger Department of Business, Management, and Accounting for use in all senior capstone courses. An agreement has been reached with WebCT to pilot their new electronic portfolio product. The portfolio has been structure around the department's student learning outcomes and it is the responsibility of the students to select artifacts that demonstrate mastery of these outcomes as well as the author meaningful explanatory reflections.

The student capstone portfolio will be assessed by multiple assessors applying standards communicated through a rubric. The e-portfolio model is preferred due to the accessibility, flexibility, and professional usefulness.

\section{Summary and Future Work}

The assessment program of the Department of Business Management and Accounting is still in its infancy and, like any infant, is bound to stumble while it makes its first steps. Noteworthy in this program is the commitment by the faculty and leadership of the department, the multiple assessment methods being employed, the use of educational technologies, and the genuine dedication to improving educational effectiveness.

The department is currently exploring a variety of assessment systems in an attempt to choose one for future adoption. The goal is to have a detailed data-management system in place that will enable faculty across the department, university administrators, and accrediting agencies to review data and artifacts on a continuous basis. The use of a multi-queriable assessment database allows the department to run an extensive variety of correlations relevant to the overall quality of teaching and learning, as well as to automate administrative functions. The data-management system under consideration will include: placement-test results, grades, advisement information, participation in university activities, diagnostic scores, rubric ratings, videos, attendance information, use of remediation services, samples of student work, and other useful artifacts. For security reasons, varying levels of accessibility will be determined based on the needs of the users, and in many instances student identifiers will be removed.

To drive the assessment process, an assurance of learning committee has been established and given the charge of insuring the success of the assessment plan and annually reviewing artifacts and data in order to pinpoint areas that require action and or improvement. The committee is the decision making source that will determine if a course of action is needed as well as responsible for developing a corresponding plan. Documentation and justification for all decisions is recorded in detail. Additionally, the changes made, the implementation of the changes, the results, impact 
on student learning/performance, and successes and failures are considered and used to determine future courses of action.

\section{Lessons Learned}

Extensive investigation has illustrated not just the importance of student outcomes assessment but also the critical role that technology and e-learning strategies can play in an overall assessment program. With the increasingly dependent and vital role that technology plays in human productivity and knowledge acquisition it stands to reason that technology needs to play an important role in our efforts to evaluate instruction and learning outcomes, as well as drive the decision making that seeks to enhance educational effectiveness.

Although technology facilitates assessment and e-assessment has been identified as a best practice, the most important lesson learned is that assessment programs are time consuming efforts that require planning and foresight. Effectiveness is dependent on institutional and administrative support as well as a long range plan for sustainability that includes technological preparedness.

\section{References}

American Association for Higher Education. (2001). Electronic portfolios: Emerging practices for students, faculty and institutions. Retrieved 2/28/06 from http://aahe.ital.utexas.edu/electronicportfolios/index.html

Audette, B. (2005). Beyond curriculum alignment: How one high school is using student assessment data to drive curriculum and instruction decision making. Retrieved 1/15/06 from: http://www.nesinc.com/PDFs/2005 07Audette.pdf

Aurbach, E. (n.d.). About alternative assessment. Retrieved 2/4/06 from http://www.aurbach.com/alt_assess.html

Baratz-Snowden, J.C. (1993). Opportunity to learn: Implications for professional development. Journal of Negro Education, 62, 311-323.

Barett, H. (2004). Differentiating electronic portfolios and online assessment management systems. Proceedings of the SITE Conference. Retrieved 2/15/06 from http://electronicportfolios.com/portfolios/SITE2004paper.pdf

Bennett, R. E. (2002). Inexorable and inevitable: The continuing story of technology and assessment. Journal of Technology, Learning, and Assessment, 1 (1). Available at http://www.jtla.org

Berge, Z. L. (2002). Active, interactive and reflective eLearning. Quarterly Review of Distance Education, $3(2), 181-190)$

Bhatti, A., Tubaisahat, A., \& El-Qawasmeh, E. (2005). Using technology-mediated learning environment to overcome social and cultural limitations in higher education. Issues in Informing Science and Information Technology, 2, 67-76. Available at http://2005papers.iisit.org/I06f77Bhat.pdf

Bruce, C. (2003). Seven faces of information literacy. Retrieved 6/12/06 from: http://crm.hct.ac.ae/events/archive/2003/speakers/bruce.pdf

Buzzetto-More, N. (2006, March). The e-Learning and business education paradigm: Enhancing education, assessment, and accountability. Proceedings of the Maryland Business Education Association Conference. Ocean City, $M D$.

Buzzetto-More, N., \& Guy, R. (2006). Incorporating the hybrid learning model into minority education at a historically black university. Journal of Information Technology in Education, 5, 153-164. Available at http://jite.org/documents/Vol5/v5p153-164Buzzetto130.pdf

Chun, M. (2002). Looking where the light is better: A review of the literature on assessing higher education quality. Peer Review. Winter/Spring. 
Cooper, T. (1999). Portfolio assessment: A guide for lecturers, teachers, and course designers. Perth: Praxis Education.

Dhir, K. (2005). Content access, and the use of data for student learning: The case of Berry College. In K. Martell \& T. Calderon, Assessment of student learning in business schools: Best practices each step of the way (Vol. 1, No. 2, pp. 167-183). Tallahassee, Florida: Association for Institutional Research.

Dietal, R. J., Herman, J. L., \& Knuth, R. A. (1991). What does research say about assessment? North Central Regional Educational Laboratory. Retrieved 3/27/06 from: http://www.ncrel.org/sdrs/areas/stw esys/4assess.htm

Dodge, B. (1995). WebQuests: A technique for internet-based learning. Distance Educator, 1 (2), 10-13

Dodge, B., \& Pickette, N. (2001). Rubrics for Web lessons. Retrieved 2/12/06 from http://edweb.sdsu.edu/webquest/rubrics/weblessons.htm

Drago, W. (2004, July 23). Study: Virtual courses producing measurable gains in high-level learning. Ascribe. Retrieved 2/12/06 from http://www.ascribe.org/cgibin/spew4th.pl?ascribeid $=20040723.102807 \&$ time $=10 \% 2050 \%$

ePortConsortium.Org. (2003). Electronic portfolio white paper [Version 1.0]. Retrieved 4/14/06 from http://eportconsortium.org

Ewell, P. \& Steen, L. A. (2006). The four A's: Accountability, accreditation, assessment, and articulation. The Mathematical Association of America. Retrieved 3/13/06 from http://www.maa.org/features/fouras.html

Garrison, D., Anderson, T., \& Archer, W. (2004, May). Critical thinking, cognitive presence, and computer conferencing in distance education. Retrieved 2/12/06 from http://communitiesofinquiry.com/documents/CogPres_Final.pdf

Granland R., Bergland, E., \& Eriksson, H. (2000). Designing Web-based simulations for Learning. Future Generation Computer Systems, 17, 171-185.

Gay, W. (2005). (Almost) painless assessment: Using intake processes for assessment purposes. In K. Martell \& T. Calderon, Assessment of student learning in business schools: Best practices each step of the way (Vol. 1, No. 2, pp. 24-46). Tallahassee, Florida: Association for Institutional Research.

Haken, M. (2006, January). Closing the loop-learning from assessment. Presentation made at the University of Maryland Eastern Shore Assessment Workshop. Princess Anne: MD.

Hamilton, D. \& Shoen, E. (2005). Same song, second verse: Evaluation and improvement of an established assessment program. In K. Martell \& T. Calderon, Assessment of student learning in business schools: Best practices each step of the way (Vol. 1, No. 2, pp. 138-153). Tallahassee, Florida: Association for Institutional Research.

Harich, K., Fraser, L., \& Norby, J. (2005). Taking the time to do it right. In K. Martell \& T. Calderon, Assessment of student learning in business schools: Best practices each step of the way (Vol. 1, No. 2, pp. 119-137). Tallahassee, Florida: Association for Institutional Research.

Hersh, R. (2004, June). Assessment and accountability: Unveiling value added assessment in higher education. A Presentation to the AAHE National Assessment Conference. June 15, 2004. Denver: Colorado

Higher Education Funding Council for England. (2005). About us: History. Retrieved 3/13/06 from http://www.hefce.ac.uk/aboutus/history.htm

Kellough, R.D. \& Kellough, N.G. (1999). Secondary school teaching: A guide to methods and resources; planning for competence. Upper Saddle River, New Jersey Prentice Hall.

Kruger, D. W., \& Heisser, M. L. (1987). Student outcomes assessment: What institutions stand to gain. In D.F. Halpern (Ed.), Student outcomes assessment: What institutions stand to gain. New Directions for Higher Education (pp. 45-56). San Francisco: Jossey-Bass. 
Liam Healy \& Associates. (2003). Assessment and development centers. Retrieved 3/13/06 from http://www.psychometrics.co.uk/adc.htm

Linn, R. (2002) Assessment and accountability. Educational Researcher, 29 (2), 4-16).

Lorenzo, G, \& Ittelson, J. (2005a, July). An overview of e-portfolios. EduCause Learning Initiative Paper 1: 2005

Lorenzo, G, \& Ittelson, J. (2005b, October). Demonstrating and assessing student learning with eportfolios. EduCause Learning Initiative Paper 3: 2005

Love, T. \& Cooper, T. (2004). Designing online information systems for portfolio-based assessment: Design criteria and heuristics. Journal of Information Technology Education, 3, 65-81. Available at http://jite.org/documents/Vol3/v3p065-081-127.pdf

Lunce, L. (2004, October). Computer simulations in distance education. International Journal of Instructional Technology and Distance Education, 1 (10)

Martell, K., \& Calderon, T. (2005). Assessment of student learning in business schools: What it is, where we are, and where we need to go next. In K. Martell \& T. Calderon, Assessment of student learning in business schools: Best practices each step of the way (Vol. 1, No. 1, pp. 1-22). Tallahassee, Florida: Association for Institutional Research.

Mitchell, B. C. (2006). Using networked digital simulations in business courses. Proceedings of the UMES Office of Instructional Technology 2006 E-Learning Seminar. July 11, 2006. Princess Anne: Maryland

National Center for Postsecondary Education. (2001) Student assessment in higher education: A comparative study of seven institutions. University of Michigan.

Orlich, Harder, Callahan \& Gibson. (2004) Teaching strategies: A guide to better instruction. New York: Houghton Mifflin.

Old Dominion University. (2006). The history of assessment at Old Dominion University. Retrieved 3/13/06 from http://www.odu.edu/webroot/orgs/ao/assessment.nsf/pages/history page

Page. D.(2006). 25 tools, technologies, and best practices. T. H. E. Journal, 33 (8). Retrieved from http://thejournal.com/articles/18042

Petrides, L. (2006). Data use and school reform. T. H. E. Journal, 33 (8). Retrieved 3/13/06 from http://thejournal.com/articles/18041

Petkov, D. and Petkova, O. (2006). Development of scoring rubrics for IS projects as an assessment tool. Issues in Informing Science and Information Technology Education. 3, 499-510). Available at http://informingscience.org/proceedings/InSITE2006/IISITPetk214.pdf

Pellegrino, J., Chudowsky, N., \& Glaser, R. (2001). Knowing what students know. The science and design of educational assessment. Washington, DC: National Academy Press.

Pearson, D., Vyas, S., Sensale, LM, \& Kim, Y. (2001). Making our way through the assessment and accountability maze: Where do we go now? The Clearing House, 74 (4), 175-191.

Popper, E. (2005). Learning goals: The foundation of curriculum development and assessment. In K. Martell \& T. Calderon, Assessment of student learning in business schools: Best practices each step of the way (Vol. 1, No. 2, pp. 1-23). Tallahassee, Florida: Association for Institutional Research.

Ridgway, J., McCusker, S., \& Pead, D. (2004). Literature Review of e-Assessment. Bristol, UK: Nesta Future Lab.

Schneider, C. G. (2002). Can value added assessment raise the level of student accomplishment? Peer Review, Winter/Spring 2002. Retrieved from http://www.aacu.org/peerreview/pr-sp02/prsp02feature1.cfm

Swearington, R. (n.d.). A primer: Diagnostic, formative, \& summative assessment. Retrieved 2/4/06 from http://www.mmrwsjr.com/assessment.htm 
Urciuoli, B. (2005). The language of higher education assessment: Legislative concerns in a global context. Indiana Journal of Global Legal Studies, 12 (1), 183-204.

Vendlinski, T., \& Stevens, R. (2002). Assessing student problem-solving skills with complex computer based tasks. Journal of Technology, Learning, and Assessment, 1 (3). Available at http://escholarship.bc.edu/jtla/vol1/3]

Walcott, S. (2005) Assessment of critical thinking. In K. Martell \& T. Calderon, Assessment of student learning in business schools: Best practices each step of the way (Vol. 1, No. 1, pp. 130-155). Tallahassee, Florida: Association for Institutional Research.

Walvoord, B. E., \& Anderson, V. J. (1998). Effective grading: A tool for learning and assessment. San Francisco: Jossey-Bass

Wiggins, G. (1990). The case for authentic assessment. Practical Assessment Research and Evaluation, 2(2).

Wright, B. (2004, October 1). An assessment planning primer: Getting started at your own institution. Presentation Made at the $13^{\text {th }}$ Annual Northeast Regional Teaching Workshop.

Wu, D, \& Hiltz, R. (2004, April). Predicting learning from asynchronous online discussions. Journal of Asynchronous Learning Networks, 8 (2), 139-152.

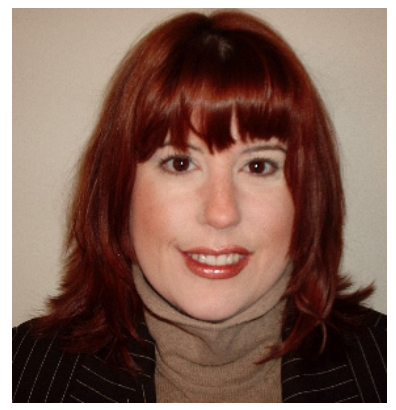

\section{Biographies}

Dr. Nicole A Buzzetto-More is an assistant professor and business education program coordinator at the University of Maryland Eastern Shore. Originally from New York, she has a doctorate in Communications and Instructional Technology from Columbia University, a masters in education in Communications and Instructional Technology from Columbia University, a masters of science in Communications from the College of New Rochelle, and a bachelor of arts degree from Marist College. Her intellectual interests include the uses of digital technologies to augment teaching, learning, and assessment. She holds several grants that support her various instructional technology research and development projects. She has published numerous papers in referred journals and is a frequent presenter at conferences across the globe. In 2005 she was honored by the American Distance Education Consortium. She is currently working on her first book to be published by Informing Science Press in early 2007.

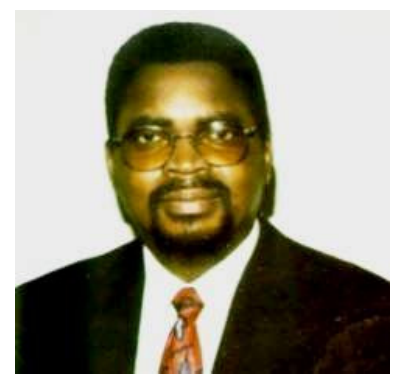

Dr. Ayodele Julius Alade is interim dean of the School of Business and Technology at the University of Maryland Eastern Shore. Originally from Nigeria, he has degrees from Cuttington University in Liberia and the University of Utah. His areas of specialization include: operations management, quantitative methods, international and developmental economics, industrial economics, and corporate finance. His publications, presentations, and grantsmanship are interdisciplinary and international in scope. 